\title{
電子レンジ用ハイパワーセンサを用いた冷凍食品の解凍検出
}

\author{
正員 寉田 哲男 (東京理科大学) \\ 正員 越地 耕二 (東京理科大学)
}

\author{
非会貝 菊池 嚴夫 (日立ホームデック) \\ 非会員 周 英明 (東京理科大学)
}

\section{Defrosting Detection for Frozen Foods using High Power Sensor for Microwave Oven}

Tetsuo KUBOTA, Member (Science University of Tokyo), Itsuo KIKUCHI, Non-Member (Hitachi Hometec, Ltd.) Kohji KOSHIJI, Member, Eimei SHU, Non-Member (Science University of Tokyo)

キーワード：電子レンジ, マイクロ波, 方向性結合器, 冷凍食品, 解凍

\section{1. まえがき}

冷涷食品の普及に伴って手早く解凍できる電子レンジを 用いての解凍が一般家庭では行われるようになっている。

ところが電子レンジにおいての解凍は、冷凍食品の初期 冷凍保存温度の違い、あるいは冷凍状態から解凍状態に移 る過程での食品のマイクロ波誘電特性の著しい変化により 解凍むらが生じるため、冷涷食品を失敗なく解凍できる電 子レンジの開発か望まれている。本報告ではこれらの点に 注目し、先に提案した電子レンジ用に開発したガラスエポ キシ両面基板上に構成したループ型方向性結合器方式の八 イパワーセンサを用いて ${ }^{(1)}$ 、冷凍食品の解凍に至るまでの 状態変化を、伝送されるマイク口波の反射係数「から捉え、 最適解凍状態の検出を試みた。

\section{2. 冷東食品のマイクロ波に対する誘電特性}

マイクロ波は食品（誘電体）に照射されると食品内部に 浸入して誘電体損失として発熱する。このときの単位体積 あたりの誘電体損失 $\mathrm{P}$ は、周波数を $\mathrm{f}(\mathrm{Hz})$ 、電界を $\mathrm{E}(\mathrm{v} / \mathrm{m}) 、$ 比誘電率を $\varepsilon_{\mathrm{r}}^{\prime}$ 、誘電正接を $\tan \delta$ 之すると、

$$
\mathrm{P}=0.556 \times 10^{-10} \mathrm{fE}^{2} \varepsilon_{\mathrm{r}} \cdot \tan \delta \quad\left(\mathrm{W} / \mathrm{m}^{3}\right) \cdots(1)
$$

により定まる。ここで、 $\varepsilon_{\mathrm{r}}^{\prime} \cdot \tan \delta$ を損失係数 (loss factor）と呼び、マイクロ波加熱の目安としている(2)。こ の損失係数は、食品の種類や温度等により変化する。特に 温度による損失係数の変化は著しく、食品の冷凍状態、冷 葴状態、および常温状態では図1 に示すように大きく異な った值をとる ${ }^{(3)}$ 。図1 から食品が冷凍された状態では、冷 蔵、常温状態に比べ損失が少なく、冷蔵、常温状態では損 失がきわめて大きいことが解る。また冷凍状態から冷蔵状 態に移る過程に損失係数が急激に变化する最大水結晶生成 帯 ( $-5^{\circ}$ C - $1^{\circ}$ C近傍) 亡称する温度領域があり、この領 域で食品は調理のしやすい最適解凍状態となっている。し たがって、この損失係数の変化が捉えられれば食品の解凍 状態を検出することができる。そこで、ハイパーワセンサ を用いて、これらの誘電特性の変化を、反射係数「の変化
で捉え最適解凍状態の検出を試みた。反射係数「は食品に マイクロ波が照射された時の入射波と反射波の比から求め られ、入射波電圧をVi、反射波電圧を $V r$ とすると、

$$
\Gamma=V_{r} / V_{i}=|\Gamma| e^{j o}
$$

で表される(4)。

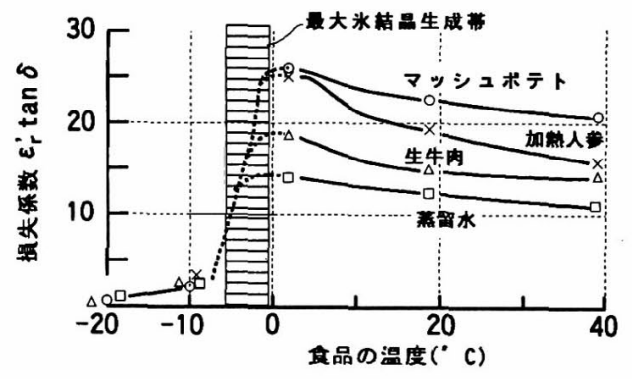

図1 食品の温度と損失係数

Fig. 1 Loss factor of various foods as a function of temperature.

\section{3.ハイパワーセンサによる解東状篂の検出}

図2 にマイクロ波加熱したときの冷凍食品の温度に対す る反射係数 $\Gamma$ 変化を、ハイパワーセンサを用いて検出す るための測定系を示す。

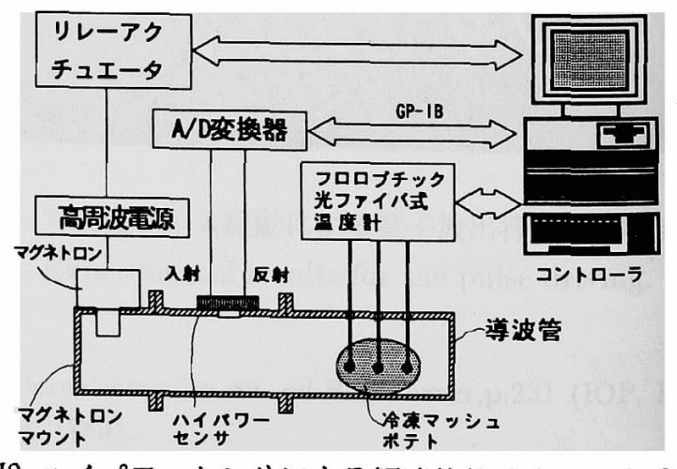

図2 ハイパワーセンサによる解凍状態検出の測定系

Fig. 2. Measurement system for defrosting detection using High Power Sensor. 
ここでは、冷凍食品を終端部を短絡した導波管（WRJ-2） の内部に挿入し、発振周波数 $2450(\mathrm{MHz})$ のマグネトロンによ り加熱を行っている。反射係数検出のためのハイパワーセ ンサは2450( $\mathrm{MHz})$ における結合度が43. 6(dB)、方向性が 20.6(dB)で (1) 、マグネトロンマウントと冷凍食品の挿入さ れている導波管の間に挿入され、図3 に示すように導波管 天井部中央のスリット部に設置されている。

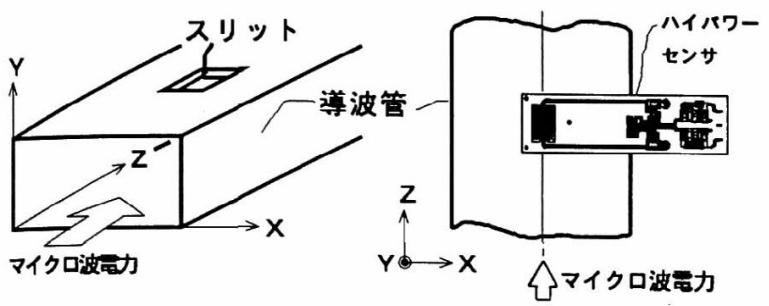

四3 導波管のスリット部に設けられたハイパワーセンサ

Fig. 3. High Power Sensor attached to slit on the waveguide wall.

マイクロ波加熱中の食品の温度測定には、光ファイバの 先端に蛍光体を叙布した素子からなるフロロプチック光フ ァイバ式温度計（LUXTRON model-755）を用い、マイクロ波 に対する相互の影響をなくしている。マグネトロンの出力 は約300Wで、冷凍食品として、それぞれ50、100、200gの冷 凍マッシュポテトを用いた。ハイパワーセンサからの入射 波電圧および反射波電压の検波出力之冷凍マッシュポテト の温度データはマイクロ波加熱中パーソナルコンピュータ により毎秒1個の割合で自動測定され、各温度ことの反射係 数「を計算している。図4 にこの測定結果を示す。

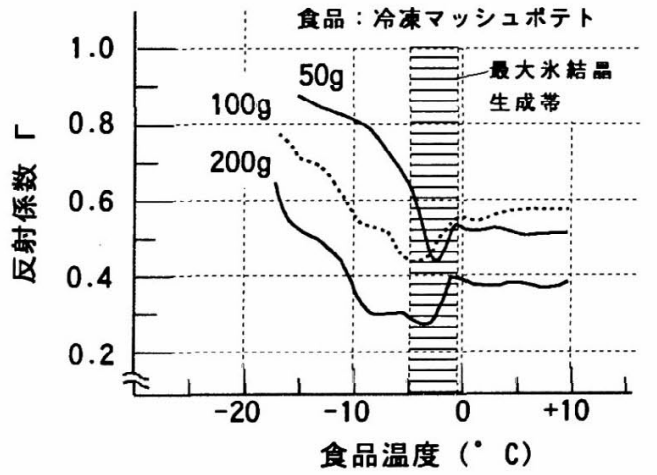

図4 冷凍マッシュポテトの温度と反射係数の測定結果

Fig. 4. Reflection coefficient of frozen mashed potato as a function of temperature obtained from measurement.

図4において反射係数 $\Gamma$ は $-20^{\circ} \mathrm{C \sim}-10^{\circ} \mathrm{C}$ 近傍では大き な値をとるか、温度が最大水結晶生成带に近つくにつれて 減少して、最大水結晶生成帯において最小值をとり、さら に温度の増加とともに上昇に転じていることがわかる。冷 凍食品サンプルとしてこの他に冷凍マグロ、冷凍エビ、冷 凍ロールイカについても同様の結果が得られた。これらの
結果は、最大水結晶生成带内にある反射係数 $\Gamma$ の最小值を 捉えることにより最適解凍状態の検出が可能であり、ハイ パワーセンサによりこの状態の検出が出来ることを示して いる。

\section{4.まとめ}

ループ型方向性結合器から成る電子レンジ用ハイパワー センサで測定される反射係数「を用い、冷凍食品の最適解 凍状態の検出が可能であることを確認した。今後はさらに 重量センサ等を併用したきめ細かな解凍検出を試みたい。

\section{文献} (平成7年10月5日受付)

（1）寉田哲男, 越地耕二, 周英明:「電子レンジ用ハイパワー センサ」, 電学論Vol. 115-D, N012, 1551〜1552(1995)

(2)山下榮吉:「応用電磁波工学」, 近代科学社, 193 198 (1992)

(3)N. E. Bengtsson, P. 0. Risman: "Dielectric Properties of Foods at $3 \mathrm{GHz}$ as Determined by a Cavity Perturbation Technique ", Journal of Microwave Power (6) $2,107 \sim 123(1971)$

（4）中島将光:「マイクロ波工学」, 森北出版, 14 15(1975)

窪田 哲男 （正員）1949年10月生. 72年千葉工業大学電

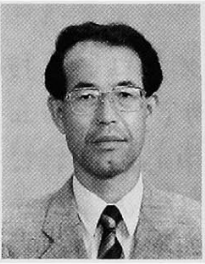
子工学科卒業. 72年 (株) 日立ホームテッ ク入社, 96年4月より東京理科大学大学院理 工学研究科に社会人入学, 電子レンジに関 するマイクロ波技術開発の研究に従事, 82年日本電機工業会技術賞受賞. IEEE, 電子 情報通信学会, 日本家政学会会員. （非会員）1941年8月生. 65年茨城大学工学

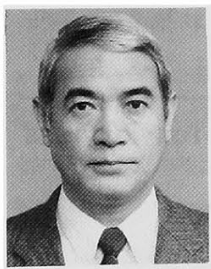
部電気工学科卒業. 65年日立熱器具 (株) 入社 (現在 (株) 日立ホームテックに社名 変更）,92年（株）日立製作所ライティン グ事業部熱器部部長を経て95年から（株） 日立ホームテック設計部長.

（正員）1947年7月生. 78年東京理科大学大

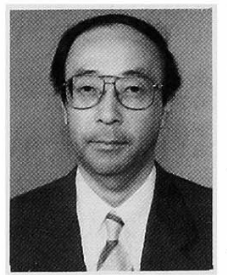
学院理工学研究科博士課程修了. 電波シス テム, 環境電磁工学, 医用電子工学の研究 に従事, 現在同大学理工学部助教授. 工学博士. IEEE, ASAI0, 電子情報通信学会, 日本人工臟器学会, 日本ME学会, 回路実装学 会等の会員.

（非会員）1933年7月生. 56年6月台湾大学

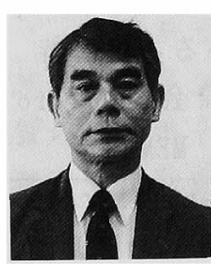
工学部電機工学科卒業. 68年3月東京大学 大学院工学研究科電子工学専攻博士課程 修了. マイクロ波回路、医用電子工学, プリ ント回路の電磁特性の研究に従事, 現在東 京理科大学理工学部教授. 工学博士. 